\title{
Penerapan Business Model Canvas dan Proyeksi Analisis Finansial Sebagai Solusi Keberlangsungan Kegiatan UMKM di Pamulang
}

\author{
Angela Gita Prameswari' ${ }^{1}$, Fitryah Nurhidayah ${ }^{2}$ \\ ${ }^{1,2}$ Program Studi Akuntansi \\ Universitas Pembangunan Jaya, Jl. Cendrawasih Raya Blok B7/P, Sawah Baru, Kec. \\ Ciputat, Kota Tangerang Selatan, Banten ${ }^{1,2}$ \\ Email : angela.gita@student.upj.ac.id ${ }^{1}$, fitriyah.nurhidayah@upj.ac.id ${ }^{2}$
}

\begin{abstract}
ABSTRAK
Kegiatan Wirausaha menjadi salah satu cara untuk menggerakkan perekonomian di Indonesia, karena dapat berkontribusi dalam penyerapan tenaga kerja. Kegiatan Wirausaha ini biasa disebut dengan Usaha Mikro, Kecil, dan Menengah (UMKM). Jumlah pelaku UMKM di Indonesia terus meningkat setiap tahunnya, termasuk di daerah Pamulang. UMKM yang bergerak dalam bidang sejenis dapat menjadi pesaing bisnis. Perancangan dan perencanaan bisnis serta proyeksi analisis finansial yang kurang matang akan menimbulkan beberapa permasalahan, baik dari dalam maupun dari luar lingkungan bisnis yang nantinya bila dibiarkan secara terus menerus akan menyebabkan kalah saing. Penelitian ini bertujuan agar para pelaku bisnis dapat merancang strategi bisnis baru berdasarkan pendekatan Business Model Canvas dan melakukan proyeksi analisis finansial. Dalam penelitian ini, peneliti menggunakan metode penelitian kualitatif dan literatur review. Pengumpulan data dilakukan dengan melakukan survei menggunakan kuesioner. Hasil dari penelitian ini menunjukkan referensi rancangan strategi baru dari sembilan blok elemen yang terkandung dalam Business Model Canvas dengan memperhatikan matrik SWOT serta perhitungan proyeksi analisis finansial sebagai solusi keberlangsungan kegiatan UMKM di daerah Pamulang. Penelitian ini masih terbatas dalam pencarian responden akibat adanya pandemi Covid19. Penelitian ini digunakan bagi para pelaku UMKM yang berada di daerah Pamulang.
\end{abstract}

Kata kunci: Business Model Canvas, Keberlangsungan Usaha, Model Bisnis, Proyeksi Analisis Finansial, Strategi Baru.

\section{ABSTRACT}

Entrepreneurial activity became one of the economic drivers in Indonesia, because it can contribute to absorbs the manpower. This entrepreneurial activity is commonly reffed to as Micro, Small and Medium Enterprises (MSME). The number of MSME in Indonesia continues to increase every year, including in Pamulang. MSMEs that are engaged in similar fields can become a business competitor. Unpreapared business planing and financial analysis projections will cause several problems, both from inside and outside the business environment, and it would be beating our business if the business owner don't fix the problems. This study aims to enable the business owner to design new business strategy based on Business Model Canvas approach and do the analysis financisl projection. In this study, researchers used qualitative research methods and literatur review. The data was collected by conducting a survey using a questionnaire. The results of this study indicate a reference to the new strategy design of the 
nine element blocks contained in Business Model Canvas by paying attention to the SWOT matrix and the calculation of financial analysis projection as a solution to MSME sustinability in Pamulang. This research is still limited to find respondents due to Covid-19 pandemic. This research also used for Pamulang MSME.

Keywords : Business Model Canvas, Business Sustainability, Business Model, Financial Analysis Project, New Strategy.

\section{PENDAHULUAN}

Pengangguran merupakan masalah yang dihadapi oleh setiap negara termasuk Indonesia. Jumlah penduduk Indonesia yang sangat tinggi di mana BPS sudah memproyeksikan bila jumlah penduduk Indonesia di tahun 2020 akan mencapai angka 271.066.000 jiwa membuat banyak orang kesulitan dalam memperoleh pekerjaan (Gischa, 2020). Pada kenyataannya sangat disayangkan bahwa lapangan pekerjaan yang ada tidak diimbangi dengan bertambahnya jumlah pencari kerja. Badan Pusat Statistik (BPS) merilis bahwa Tingkat Pengangguran Terbuka (TPT) sampai pada bulan Februari tahun 2020 sebesar 4,99\% (BPS, 2020). Kondisi ini akan semakin diperburuk dengan situasi persaingan global yang membuat masyarakat Indonesia harus dapat bersaing dengan masyarakat dari berbagai negara. Selain itu pendemi Covid-19 juga sangat berpengaruh pada penyerapan tenaga kerja karena memberikan efek buruh pada perekonomian diseluruh dunia.

Ada bayak ide kreatif yang dapat dikembangkan untuk menjadi suatu hal yang menghasilkan bagi diri sendiri maupun masyarakat sekitar. Berwirausaha atau mendirikan usaha yang igolongkan kedalam Usaha Mikro, Kecil dan Menengah (UMKM) dapat dijadikan sebagai salah satu cara untuk mengurangi pengangguran di Indonesia. Semakin hari semakin banyak UMKM bermunculan baik di kota maupun daerah. Hal ini dijadikan sebagai sarana untuk mengembangkan dan menyalurkan ide-ide kreatif dan inovatif yang berkembang di masyarakat. Setiap pribadi memiliki potensi untuk menghasilkan ide yang luar biasa dalam bidang apapun, termasuk ide bisnis. Ide yang ada akan menjadi sesuatu hal istimewa jika dapat dieksekusi dengan baik. Namun, jika sebuah ide dieksekusi secara langsung tanpa perencanaan yang matang maka dapat mengakibatkan pemborosan biaya dan waktu. Maka dari itu, diperlukan suatu cara untuk dapat mengeksekusi sebuah ide 
bisnis dengan cara yang cepat, tepat, efektif dan efisien (Hermawan \& Pravitasari, 2013).

Berwirausaha menjadi salah satu kegiatan yang banyak dilakukan oleh masyarakat di tengah berkembangnya dunia bisnis pada era globalisasi yang juga didukung oleh kemajuan teknologi. Pada kenyataannya, masih banyak pelaku usaha yang tidak mempersiapkan dan merancang kegiatan usaha secara matang seperti tidak melakukan riset lokasi, tidak melakukan riset keinginan pasar, tidak menemukan supplier bahan baku yang terpercaya sebelum memulai usaha, tidak optimalnya dalam promosi produk, serta tidak melakukan peritungan biaya yang matang. Oleh sebab itu, membangun sebuah kegiatan usaha dapat didukung dengan sebuah model bisnis yang disebut dengan Business Model Canvas (BMC) (Hengki, Rizan, 2016). Model bisnis (business model) merupakan alat yang banyak dipakai untuk mengubah ide menjadi sebuah bisnis. Model bisnis digunakan untuk menyederhanakan elemen-elemen bisnis yang kompleks menjadi elemen-elemen pokok yang mudah untuk dibuat. Business Model Canvas (BMC) merupakan salah satu alat model bisnis yang cukup populer dalam dunia kewirausahaan karena memiliki kemampuan untuk menggambarkan elemen inti yang dibutuhkan dari sebuah bisnis yang dibagi ke dalam sembilan poin penting dan dituangkan dalam satu lembar kanvas. Business Model Canvas $(B M C)$ dapat digunakan untuk berbagai macam kondisi bisnis, baik untuk bisnis kecil maupun besar, bahkan untuk bisnis yang sedang berlajan ataupun bisnis yang baru akan dibangun. $B M C$ terdiri dari 9 blok elemen, yaitu Customer Segments, Value Propositions, Channels, Customer Relationship, Revenue Streams, Key Resources, Key Activities, Key Partnership dan Cost Structure.

Ketatnya persaingan dalam kegiatan usaha membuat para pelaku usaha harus dapat dengan cermat melihat peluang dengan menganalisis sembilan elemen penting kegiatan usaha yang terdapat pada Business Model Canvas (BMC). Setelah melakukan analisis kekuatan dan kelemahan yang dimiliki dari suatu kegiatan usaha, maka dibutuhkan suatu perencanaan terkait strategi model bisnis yang akan diterapkan ditengah ketatnya persaingan bisnis, agar para pelaku usaha dapat terus beradaptasi dengan perubahan yang terjadi di lingkungan luar organisasinya yang akan berdampak terhadap keadaan finansial perusahaan. Kesalahan suatu strategi yang diterapkan dalam menjalankan usaha akan berdampak pada keadaan finansial 
yaitu tingkat pendapatan atau profit suatu usaha. Sementara itu strategi yang tepat untuk menjalankan suatu bisnis dengan mengoptimalkan sumber daya dan peluang yang dimiliki dapat memberikan tingkat pendapatan atau profit yang maksimal.

Setiap pelaku usaha pasti memiliki alasan dan tujuan yang berbeda dalam mendirikan kegiatan usaha. Salah satu tujuan didirikannya kegiatan usaha adalah untuk mencari laba atau keuntungan dari seluruh aktivitas yang dilakukan. Walaupun ada juga yang yang bersifat sosial dengan tujuan untuk membantu masyarakat sekitar yang membutuhkan. Ada juga yang didirikan dengan tujuan keduanya. Usaha yang dibagun dengan tujan untuk memaksimalkan laba harus dapat menyusun strategi agar dapat mengetahui seberapa lama pengembalian dana yang dikeluarkan untuk usaha dapat kembali. Peritungan tersebut dapat disusun sebelum memulai usaha agar dapat mengetahui pada jangka waktu usaha dapat memberikan laba finasial seperti yang diharapkan. Selain itu usaha yang dijalankan juga dapat memberi manfaat bagi seluruh anggota yang terlibat dalam kegiatan usaha dan juga masyarakat sekitar. Melakukan proyeksi analisis finansial membantu para pelaku usaha untuk mengetahui 2 (dua) blok elemen finansial yang terdapat di dalam Business Model Canvas (BMC) yaitu, cost structure dan juga revenue streams sehingga dapat memperoleh laba yang maksimal (Wisnu, 2014).

Berdasarkan latar belakang di atas, untuk mengetahui peran penerapan Business Model Canvas sebagai solusi keberlangsungan kegiatan wirausaha di daerah Pamulang, dirumuskan permasalahan berikut: (1) Apakah para pelaku usaha telah mendapatkan keuntungan yang maksimal dari kegiatan usahanya, (2) Apakah para pelaku usaha mengenal Business Model Canvas (BMC), (3) Apakah para pelaku usaha telah menyusun dan menerapkan Business Model Canvas (BMC) sebelum dan sesudah memulai kegiatan usaha, (4) Apa peran Business Model Canvas (BMC) dan proyeksi analisis finansial bagi kegiatan wirausaha di daerah Pamulang? Tulisan ini bertujuan untuk memberikan telaah literatur mengenai konsep dan juga praktik Business Model Canvas (BMC) dalam kegiatan usaha, khususnya di daerah Pamulang. Selain itu untuk mengetahui sejauh mana para pelaku usaha dalam mengetahui, mengenal serta menerapkan Business Model Canvas (BMC) dan proyeksi analisis finansial untuk membangun kegiatan usaha. Hal-hal yang akan dibahas dalam tulisan ini antara lain mengenai konsep menyusun Business Model 
Canvas (BMC) dan proyeksi analisis finansial serta peran Business Model Canvas $(B M C)$ dan proyeksi analisis finansial bagi keberlangsungan kegiatan usaha di daerah Pamulang terutama elemen revenue streams dan cost structure.

Kegiatan wirausaha semakin gencar dilakukan dikalangan masyarakat. Persaingan bisnis, baik bisnis jasa maupun bisnis barang di era modern ini tidak dapat dipungkiri. Sama hal nya dengan Usaha Mikro, Kecil dan Menengah (UMKM). UMKM menjadi suatu hal yang sangat penting untuk terus dikembangankan dan dipertahankan agar dapat mengatasi berbagai masalah ekonomi dan sosial, serta sebagai upaya mengatasi pengangguran dan pengentasan kemiskinan (Khodijah \& Ghina, 2016). UMKM dapat pula dijadikan sebagai suatu wadah untuk menyalurkan kreatifitas serta mendorong sumber daya manusia menjadi lebih produktif sehingga bangsa Indonesia dapat bersaing di masa depan. Hal ini dibuktikan bahwa UMKM dapat menjadi kekuatan ekonomi kreatif Indonesia ketika terjadi krisis ekonomi pada tahun 1998 dan sektor UMKM pun telah terbukti menjadi pilar perekonomian tangguh (Kurniawan, 2017).

Suatu model bisnis mencakup seluruh kunci struktural dan operasional dari suatu kegiatan bisnis. Dengan menerapkan model bisnis yang tepat pada suatu kegiatan usaha maka dapat menghasilkan dan meningkatkan pendapatan dan keuntungan usaha serta memiliki daya saing yang kuat sehingga dapat bertahan dalam dunia usaha/bisnis (Assauri, 2016). Dalam tulisannya, Osterwalder \& Pigneur menyatakan bahwa sebuah model bisnis dapat dengan sangat baik dijelaskan melalui 9 (sembilan) blok elemen yang memperlihatkan tentang bagaimana cara berfikir dan menghasilkan uang dari suatu kegiatan usaha/bisnis yang biasa disebut dengan Business Model Canvas (BMC) (Osterwalder \& Yves, 2012).

Strategi bisnis (business strategy) merupakan sebuah strategi bisnis yang digunakan untuk meningkatkan persaingan yang ada di dalam suatu industri atau segmen pasar tertentu (Solihin, 2012). Strategi bisnis juga digunakan untuk mencapai dan menetapkan tujuan yang diinginkan dari suatu kegatan usaha/bisnis. Dengan adanya strategi bisnis suatu kegiatan usaha dapat mengatasi ketidakpastian dan juga risiko yang mungkin saja terjadi selama kegiatan usaha berlangsung. Dengan mengetahui model bisnis yang tepat maka strategi bisnis yang akan disusun akan menjadi lebih 
efektif dan efisien sehingga dapat mengoptimalkan segala jenis sumber daya eksternal maupun internal yang dimiliki oleh para pelaku usaha (Permana, 2013). Kesuksesan dari suatu kegiatan UMKM dapat dilihat dari bagaimana cara si pelaku usaha untuk terus belajar, beradaptasi, berinovasi dan menyesuaikan kegiatan usaha dengan perubahan lingkungan baik eksternal maupun internal. Menciptakan peluang bisnis memerlukan sebuah antusiasme, keterampilan melihat lingkungan sekitar, komitmen dan juga strategi jangka panjang yang baik untuk dapat menjadi yang pertama dalam melakukan usaha dalam suatu kondisi tertentu. Kemampuan untuk melihat adanya peluang bisnis dapat diperoleh melalui pelatihan dan juga pendidikan kewirausahaan maupun lokakarya. Oleh karena itu, kemampuan pengidentifikasian peluang bisnis harus dikembangkan dari waktu ke waktu. Pengidentifikasian peluang yang tepat dapat membuat kegiatan usaha berjalan dengan baik dan dapat berkembang pesat (Nasip, 2017).

Business Model Canvas (BMC) diciptakan oleh Osterwalder \& Yves Pigneur pada tahun 2010. Mereka mangatakan bahwa Business Model Canvas (BMC) merupakan sebuah model bisnis yang menggambarkan secara logis bagaimana sebuah organisasi dalam menciptakan sebuah nilai. Business Model Canvas BMC) sendiri merupakan sebuah model bisnis yang digunakan untuk mengubah suatu konsep bisnis yang rumit menjadi lebih sederhana yang kemudian ditampilkan dalam satu lembar kanvas (canvas). Satu lembar kanvas tersebut berisi sebuah rencana bisnis yang terdiri dari 9 blok elemen penting yang dibutuhkan untuk memulai suatu usaha, yang kemudian dipisahkan menjadi sisi kreatif (komponen sebelah kanan) dan sisi logik (komponen sebelah kiri). Sembilan blok dalam kanvas ini mencakup analisis strategi secara internal maupun secara eksternal. Ke-sembilan blok elemen itu terdiri dari Customer Segment, Value Proposition, Customer Relationship, Channels, Revenue Streams, Key Resources, Key Activities, Key Partnership, dan Cost Structure.

Customer Segment, merupakan elemen yang digunakan untuk menentukan target pasar dari bisnis yang hendak didirikan dan dikembangkan. Pelaku usaha harus dapat mengetahui produk apa yang sesuai dengan keinginan, daya beli, lokasi, dan sumber daya yang ada. Value Proposition, merupakan sebuah nilai tambah (value) yang diberikan kepada para pelanggan. Dalam segmen ini pelaku usaha harus dapat 
memperkirakan dan memenuhi kebutuhan customer yang telah diidentifikasikan pada customer segment. Value tersebut yang akan menjadi nilai inti dari kegiatan usaha. Ada beberapa hal yang dapat dilakukan untuk membentuk nilai tambah (value), seperti berinovasi untuk menciptakan hal baru, meningkatkan kinerja dan kualitas produk, menerima customization sesuai keiinginan pelanggan, meningkatkan kenyamanan, mempermudah akses pelanggan untuk menjangkau suatu produk ataupun jasa yang ditawarkan. Channel, merupakan cara yang digunakan untuk mencapai pelanggan. Distribusi, komunikasi, dan jaringan penjual merupakan salah satu usaha untuk melakukan komunikasi dengan para pelanggan. Channels dibagi ke dalam 5 (lima) fase yaitu awareness, evaluation, purchase, delivery, dan aftersales.

Customer Relationship, memberikan gambaran mengenai hubungan antara perusahaan dengan pelanggan (customer). Hubungan yang akan dijalin dengan para pelanggan dapat dilakukan dengan secara giat mencari pelanggan baru (customer acquisition), berusaha untuk mempertahankan pelanggan yang sudah ada (customer retention), serta mendorong pelanggan yang ada untuk berbelanja lebih banyak bagi perusahaan (boosting sales) dengan memberikan berbagai macam penawaran menarik seperti diskon pelanggan dan lain lain. Menjaga hubungan baik dengan pelanggan juga dapat menjadi salah satu aspek untuk mempertahankan keberlangsungan kegiatan wirausaha (Nasip, 2017). Revenue Streams merupakan gambaran pedapatan yang akan diterima suatu perusahaan dalam bentuk uang yang berasal dari masing-masing customer segments atau dari pelanggannya. Key Resources, dibentuk berdasarkan tipe model bisnis dan merupakan sumber daya utama yang dibutuhkan oleh suatu perusahaan agar usahanya dapat berjalan. Sumber daya ini memungkinkan perusahaan untuk menawarkan value propositions, mengawasi hubungan dengan segmen pasar, mendapatkan pasar, dan memperoleh penghasilan. Key resources dapat berupa finansial, benda fisik, manusia, intelektual, teknologi, maupun saluran distribusi.

Key Activities, merupakan sebuah kegiatan atau aktivitas-aktivitas utama yang dilakukan oleh setiap perusahaan ataupun organisasi agar dapat mengoperasikan usahanya dengan sukses serta memberikan nilai tambah. Key activities dibuat sesuai dengan model bisnis. Untuk aktivitas utama pada pabrik pembuatan barang maka 
key activities yang dilakukan adalah operasi produksi. Untuk aktivias utama kegiatan operasi bagi konsultan, rumah sakit, kendaraan online maka key activities yang dilakukan adalah operasi jasa. Sedangkan untuk aktivitas utama perancangan, pembangunan, dan pengembangan hardware dan software maka key activities yang dilakukan adalah platform dan jaringan. Key Partnership, merupakan kunci kemitraan utama dalam usaha, misalnya supplier yang dapat menjamin pasokan bahan baku didapatkan dengan harga dan kondisi yang terbaik. Suatu perusahaan menjalin kemitraan untuk berbagai alasan dan menjadi landasan model bisnis. Perusahaan membentuk kemitraan untuk mengurangi risiko, mengoptimalkan model bisnis, atau memperoleh sumber daya. Terdapat 4 (empat) jenis kemitraan: (1) Strategi antara perusahaan bukan pesaing, (2) Kemitraan strategis antar pesaing (coopetition), (3) Usaha bersama/patungan untuk membentuk bisnis baru, (4) Hubungan pembeli-pemasok sehingga dapat menjamin pasokan yang didapat dengan harga dan kondisi yang baik. Memiliki mitra yang baik maka akan memberikan optimasi dan skala ekonomi, pengurangan risiko dan ketidakpastian, serta perolehan sumber daya yang sesuai dengan kegiatan tertentu.

Cost Structure, adalah struktur biaya yang memberikan gambaran mengenai semua biaya yang diperlukan dan dikelurkan untuk dapat menjalankan suatu usaha atau bisnis sesuai dengan model bisnisnya. Elemen ini menjelaskan biaya-biaya yang harus dikeluarkan untuk menghasilkan value proposition yang ditujukan pada Customer Segments sehingga nantinya akan didapat revenue streams. Terdapat biaya tetap dan biaya variabel yang biasanya dimasukkan ke dalam sebuah cost structure. Biaya-biaya tersebut dapat lebih mudah dihitung ketika pelaku usaha telah menentukan key resources, key partnership, dan key activities. Dengan menggunakan Business Model Canvas (BMC) pada Gambar 1 (Osterwalder \& Yves, 2010), para pelaku usaha dapat melihat berbagai macam elemen dan juga unit dalam melaksanakan suatu bisnis, mulai dari proses pemesanan bahan baku, proses produksi, sampai dengan proses pemasaran. 


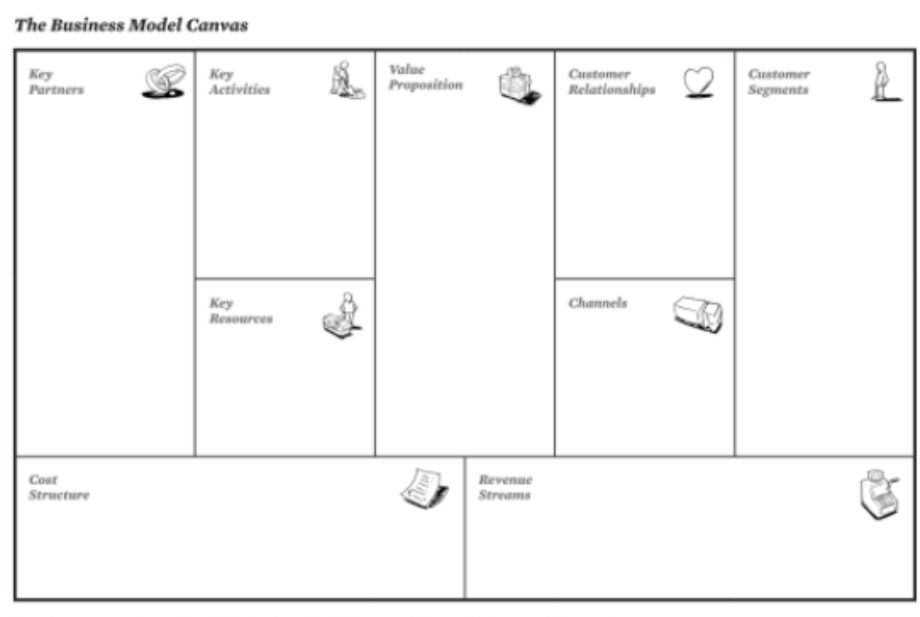

Gambar 1: Business Model Canvas

Proyeksi analisis finansial dapat dilakukan setelah menyusun Business Model Canvas. Kegiatan ini juga merupakan tahapan yang cukup penting dalam menentukan kelayakan suatu usaha ataupun bisnis Ferreira dalam (Wisnu, 2014). Terdapat 2 (dua) blok elemen yang dapat digunakan untuk membuat proyeksi analisis finansial, di antaranya adalah: (1) Revenue Stream: pendapatan yang diterima oleh UMKM dari kegiatan usaha yang dilaksanakan, baik pendapatan utama maupun pendapatan lainnya, (2) Cost Structure: biaya tetap dan biaya variabel yang dikeluarkan (biaya produksi, biaya pengembangan dan riset, biaya administrasi dan pajak, biaya marketing, biaya pengembangan dan riset dan lain-lain). Selain itu, proyeksi analisis finansial juga menampilkan perhitungan Break Event Point (BEP) dan Payback Period dari kegiatan usaha yang dijalankan (Wisnu, 2014).

\section{METODE PENELITIAN}

Desain penelitian yang digunakan adalah literature review atau tinjauan pustaka. Studi literature review merupakan cara yang dipakai untuk mengumpulkan sumber maupun data-data yang memiliki hubungan pada suatu topik tertentu untuk menjawab pertanyaan dan juga permasalahan yang ada dalam penulisan ini, yang biasanya didapat dari berbagai sumber seperti makalah, jurnal, buku, internet dan pustaka lainnya. Literature review dilakukan secara sistematis dengan mengikuti protokol dan juga tahapan yang ada agar terhindar dari bias dan pemahaman yang 
bersifat subjektif dari penelitiannya. Selain itu juga menggunakan penelitian kualitatif di mana penelitian bersifat deskriptif dan cenderung menggunakan analisis. Penelitian dilakukan selama 3 bulan, tehitung dari bulan Juni - Agustus 2020. Pada penelitian ini, pengambilan data dilakukan dengan cara menyebarkan kuesioner yang disertai dengan penjelasan singkat mengenai Business Model Canvas (BMC) kepada pada pelaku usaha. Penyebaran kuesioner dilakukan kepada 15 (lima belas) pelaku UMKM yang berperan sebagai responden yang berada di sekitar daerah Pamulang. Hal ini dilakukan untuk memperoleh data yang kuat mengenai permasalahan yang benar-benar terjadi dalam melaksanakan kegiatan usaha sehingga dapat memperoleh suatu kesimpulan yang tepat.

\section{HASIL DAN PEMBAHASAN}

\section{Gambaran Umum Objek Penelitian}

Dalam memulai suatu usaha, 9 (sembilan) elemen Business Model Canvas yang telah direncanakan secara matang akan saling melengkapi dan memudahkan pelaku usaha untuk menjadikan usaha yang didirikannya terus berkembang, berhasil dan menjadi unggul. Bila diperhatikan, banyak sekali kegiatan wirausaha yang tergolong dalam UMKM bermunculan di manapun kita berada. Tidak terkecuali di sekitar daerah Pamulang. Ada banyak masyarakat Pamulang yang memutuskan untuk melakukan kegiatan wirausaha dengan berbagai alasan yang dimiliki. Masalahnya di sini adalah, banyak sekali para pengusaha yang memiliki keinginan untuk mendirikan suatu usaha tanpa memperhatikan berbagai aspek yang sangat berpengaruh untuk keberhasilan dan keberlangsungan kegiatan usahanya. Berdasarkan hasil survei dengan menyebarkan kuesioner kepada 15 (lima belas) responden yang merupakan pelaku usaha di sekitar daerah Pamulang, Gambar 2 menggambarkan mayoritas responden sebanyak 9 dari 15 responden (60\% responden) baru saja menjalankan usaha mereka kurang dari 1 (satu) tahun. Sedangkan 4 responden (27\% responden) telah menjalankan usaha selama 1(satu) sampai 2 (dua) tahun dan hanya 2 responden ( $13 \%$ responden) yang telah menjalankan usaha selama lebih dari 2 (dua) tahun. Dalam menjalankan kegiatan usahanya sebanyak 14 responden (93\% responden) tidak memiliki karyawan dan menggunakan modal pribadi dalam membangun usaha. Sedangkan, 1 responden sisanya (7\% responden) memiliki ku- 
rang dari 3 (tiga) karyawan dan meminjam pihak ke-3 sebagai modal untuk membangun usaha.

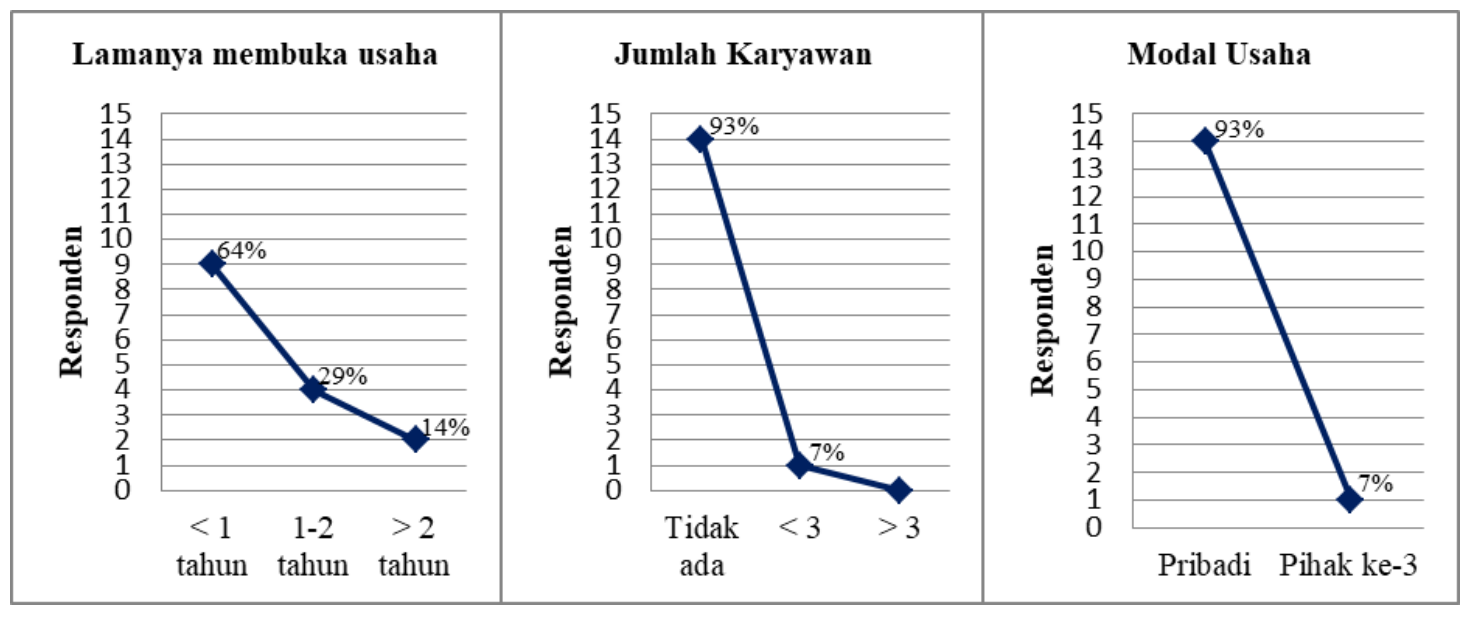

Gambar 2: Ringkasan hasil kuesioner mengenai lamanya membuka usaha, jumlah karyawan dan modal usaha

Berdasarkan hasil kuesioner, didapati berbagai macam hal dan aspek yang mendorong para responden untuk mendirikan usaha, seperti untuk mengembangkan hobi agar lebih bermanfaat, mencari penghasilan tambahan untuk membantu perekonomian, menjadi wirausaha memang merupakan tujuan utama serta untuk mengikuti trend. Gambar 3 menggambarkan keadaan selama menjalani kegiatan usaha yang mereka miliki. Delapan responden (53\% responden) menyatakan bahwa laba bersih yang mereka dapatkan selama satu bulan kurang dari Rp1.000.000 sedangkan 7 responden (47\% responden) sisanya menyatakan bahwa laba bersih yang mereka dapatkan selama satu bulan berkisar di antara Rp1.000.000 sampai Rp2.000.000. Selain itu sebanyak 10 responden (67\% responden) juga menyatakan bahwa laba bersih atau keuntungan yang diperoleh masih belum sebanding dengan biaya dan usaha yang telah dikeluarkan, sementara itu 5 responden (33\% responden) menyatakan bahwa laba bersih atau keuntungan yang diperoleh sudah sebanding dengan biaya dan usaha yang telah dikeluarkan.

Belum sesuainya laba bersih atau keuntungan yang diterima oleh para pelaku usaha ternyata dilatarbelakangi oleh beberapa masalah yang masih sering dihadapi dalam melaksanakan kegiatan usaha, di antaranya kesulitan memperoleh bahan baku, harga bahan baku yang kurang sesuai, kesulitan dalam mencari pelanggan, pencatatan dan perhitungan keuangan yang berantakan, kekurangan tenaga kerja, pengeluaran 
biaya yang tidak sebanding dengan keuntungan yang diperoleh serta kualitas bahan baku yang didapat tidak sesuai dengan yang diinginkan. Hal tersebut dianggap sebagai masalah karena dapat menghambat proses kegiatan usaha yang menyebabkan kurang maksimalnya pendapatan. Setelah penjelasan singkat mengenai Business Model Canvas (BMC) yang berlangsung seiring dengan pengisian kuesioner, penulis menemukan bahwa 13 (87\% responden) dari 15 responden yang ada belum mengetahui Business Model Canvas (BMC) saat hendak memulai usaha mereka. Sementara 2 responden (13\% responden) sisanya menyatakan bahwa mereka telah mengetahui Business Model Canvas (BMC).

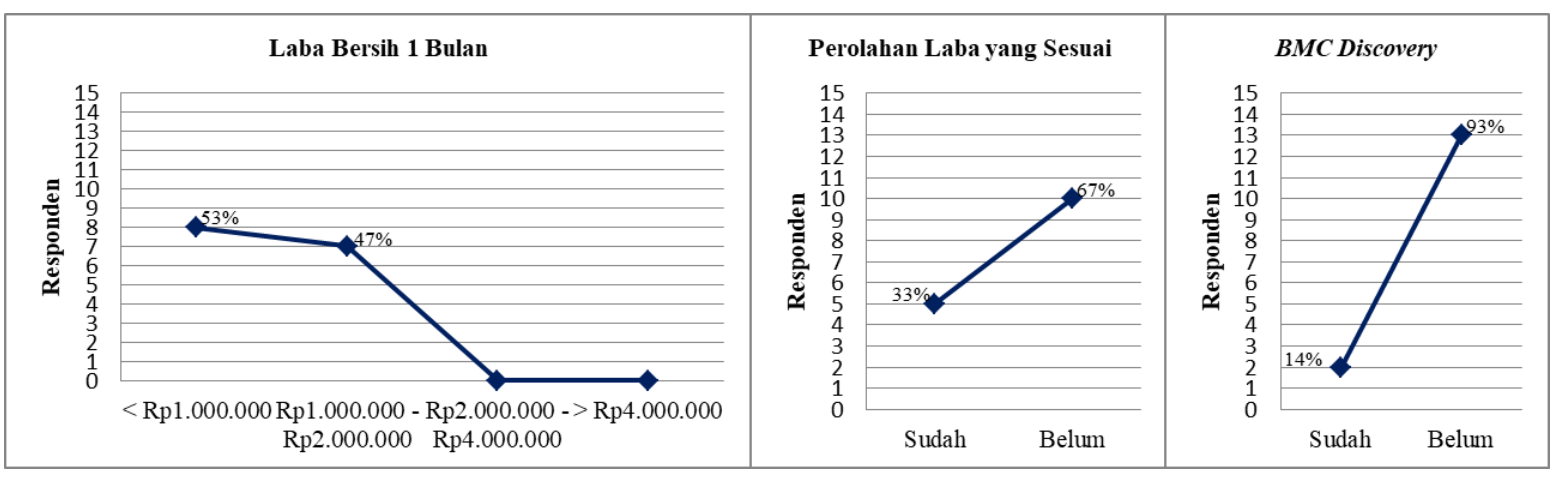

Gambar 3: Ringkasan hasil kuesioner laba bersih 1 tahun, perolehan laba yang sesuai dan BMC Discovery

Melalui analisa hasil kuesioner ini, didapati pula bahwa seluruh pelaku usaha belum merancang bisnisnya dengan model bisnis Business Model Canvas (BMC) dan merasa tertarik untuk mempelajari dan menerapkan model bisnis baru dengan menggunakan Business Model Canvas (BMC) untuk mempertahankan keberlangsungan kegiatan usaha yang dimiliki. Selain itu, responden juga merasa bahwa dengan penerapan Business Model Canvas (BMC) dapat menjadi solusi untuk mengatasi masalah yang masih sering kali dialami dalam melaksanakan kegiatan usaha dan juga dirasa dapat menjadikan kegiatan usaha yang sedang dijalani lebih efektif dan efisien.

\section{Analisis SWOT dan Penerapan Model Bisnis dengan Business Model Canvas (BMC)}

Berdasarkan hasil analisis kuesioner di atas, maka pendekatan dan penerapan model bisnis menjadi salah satu faktor penunjang keberlangsungan dan kesuksesan 
kegiatan usaha. Pendekatan model bisnis baru dengan Business Model Canvas $(B M C)$ harus disusun dengan ide kreatif dan inovatif agar mampu bertahan dan bersaing di tengah perubahan lingkungan yang amat cepat (Solihah et al., 2016). Sebelum menyusun dan menerapkan Business Model Canvas (BMC), para pelaku usaha juga perlu melakukan analisis SWOT (Strengths, Weakness, Opportunities, Threats) terhadap kegiatan usaha yang dimilikinya. Analisis ini biasanya digunakan untuk memaksimalkan kekuatan dan meminimalkan kelemahan yang menjadi faktor internal dapat mendukung dan menghambat tercapainya tujan dari suatu kegiatan. Sedangkan peluang dan ancaman yang menjadi faktor eksternal dapat memaksimalkan kemungkinan dan meminimalkan hal-hal yang bisa menonaktifkan suatu kegiatan (Phadermrod et al., 2019). Kombinasi analisis SWOT dengan Business Model Canvas (BMC) membuat pelaku usaha menjadi fokus dalam mengevaluasi elemen pendukung dan elemen penghambat dalam kegiatan bisnis yang sedang dibangunnya. Hal ini dapat memberikan suatu pemikiran dasar yang baik untuk melakukan diskusi lebih lanjut serta pengambilan keputusan yang mana akhirnya terbentuklah inovasi baru dan hal-hal yang sesuai dengan kegiatan dalam penyusunan Business Model Canvas (BMC) (Osterwalder \& Yves, 2012). Berdasarkan hal tersebut maka peneliti menyusun Matriks SWOT (Gambar 4) dan juga Business Model Canvas (BMC) (Gambar 5) yang dapat dijadikan sebagai referensi ke-15 (lima belas) responden sebagai para pelaku usaha sesuai dengan jenis usaha yang dimiliki.

\begin{tabular}{|c|c|c|}
\hline Eksternal & \begin{tabular}{l}
\multicolumn{1}{c|}{ Kekuatan $(\mathbf{S})$} \\
- Segmen yang beragam \\
- Harga terjangkau \\
- Variasi produk yang beragam \\
- Kualitas produk baik dan halal \\
- Menyediakan variasi metode pembayaran \\
dan pengiriman \\
- Menjalin hubungan baik dengan mitra \\
usaha dan pelanggan
\end{tabular} & \begin{tabular}{l}
\multicolumn{1}{c}{ Kelemahan (W) } \\
- \\
- Kergantung pada segmen yang ada \\
- Kestrbatasan sumber daya manusia \\
pelanggan \\
- Biaya untuk kegiatan produksi \\
- Lokasi yang kurang strategis \\
- Tidak ada timbal balik dari pelanggan \\
- Kesulitan memenuhi permintaan pelanggan
\end{tabular} \\
\hline \begin{tabular}{l}
\multicolumn{1}{c}{ Peluang $\mathbf{( 0 )}$} \\
Pelanggan tetap \\
subungan berkelanjutan dengan customer \\
segments \\
Mengeluarkan produk baru \\
Potensi karyawan yang baik \\
Permintaan pelangan yang meningkat \\
Promosi dari mulut ke mulut \\
Produk semakin dikenal setelah promosi
\end{tabular} & \begin{tabular}{ll} 
& \multicolumn{1}{c}{ Strategi (S.O) } \\
- & Memperluas customer segments \\
- & Menambah mitra utama \\
- & Melakukan inovasi produk \\
- Promosi media sosial dan media cetak \\
- Pelatihan kepada karyawan \\
- Peningkatan efektifitas waktu
\end{tabular} & $\begin{array}{l}\text { Strategi (W.O) } \\
\text { - Melakukan pendekatan pada customer } \\
\text { segments } \\
\text { - Melakukan survei pasar terlebih dahulu } \\
\text { - Melakukan inovasi sesuai dengan segmen } \\
\text { yang dituju } \\
\text { - Meningkatkan kualitas karyawan dengan } \\
\text { pelatihan rutin } \\
\text { - Peningkatan customer service }\end{array}$ \\
\hline $\begin{array}{l}\text { Ancaman (T) } \\
\text { - Pesaing produk sejenis } \\
\text { - Pelanggan beralih kepada pesaing produk } \\
\text { sejenis karna harga terlalu tinggi } \\
\text { - Tingkat produktivitas menurun } \\
\text { - Mualitas produk menurun } \\
\text { - Membengkaknya biaya-biaya } \\
\text { - Pubungan dengan supplier memburuk } \\
\text { Pembengkakan biaya }\end{array}$ & $\begin{array}{l}\text { Strategi (S.T) } \\
\text { - Mempertahankan harga terjangkau dengan } \\
\text { kualitas yang baik } \\
\text { - Kontrol kualitas produk secara berkala } \\
\text { - Menawarkan promo produk } \\
\text { - Menjalin hubungan kekeluargaan dengan } \\
\text { mitra, pesaing dan pelanggan } \\
\text { - Perhitungan biaya secara efisien }\end{array}$ & $\begin{array}{l}\text { Strategi (W.T) } \\
\text { - Menciptakan produk unggulan } \\
\text { - Inovasi produk dari pesaing } \\
\text { - Memberikan kartu/voucher member } \\
\text { - Penyesuaian harga produk agar tidak } \\
\text { terlalu tinggi } \\
\text { - Menjaga hubungan baik dengan mitra yang } \\
\text { dimiliki } \\
\text { - Perhitungan biaya secara efisien }\end{array}$ \\
\hline
\end{tabular}

Gambar 4: Referensi Matriks SWOT 


\begin{tabular}{|c|c|c|c|c|}
\hline \multirow[t]{2}{*}{$\begin{array}{l}\text { Key Partnership } \\
\text { - Supplier Bahan Baku } \\
\text { - Supplier Kemasan } \\
\text { - Jasa Pengiriman } \\
\text { - Networking Pengusaha } \\
\text { Sejenis }\end{array}$} & \begin{tabular}{|l|} 
Key Activities \\
- Analisis Pasar \\
- Kegiatan produksi \\
- Manajemen produk \\
- Promosi \\
- Pemesanan produk \\
- Manajemen \\
pembayaran \\
- Pengiriman roduk \\
- Retur produk \\
- Hubungan dengan \\
pelanggan \\
\end{tabular} & \multirow{2}{*}{$\begin{array}{l}\text { Value Proportions } \\
\text { Pelanggan: } \\
\text { - Produk berkualitas baik } \\
\text { - Informasi produk yang } \\
\text { lengkap } \\
\text { - Pengemasan produk yang } \\
\text { aman } \\
\text { - Akses pembelian yang } \\
\text { mudah } \\
\text { - Keamanan transaksi } \\
\text { - Metode pembayaran dan } \\
\text { pengiriman yang mudah dan } \\
\text { bervariasi } \\
\text { - Harga terjangkau } \\
\text { - Menyediakan varian olahan } \\
\text { Pemilikel Halal } \\
\text { - Customer Relationships } \\
\text { - Service terbaik } \\
\text { - Cepat dan tepat } \\
\end{array}$} & $\begin{array}{l}\text { Customer } \\
\text { Relationships } \\
\text { - Produk sesuai profiling } \\
\text { - Pelayanan ramah, } \\
\text { cepat, tepat } \\
\text { - Potongan harga } \\
\text { - Pemberian hadiah } \\
\text { - Pemberian kartu nama } \\
\text { - Kartu member/voucher } \\
\text { member } \\
\text { - Memberikan ganti rugi } \\
\text { bila menerima produk } \\
\text { dalam kondisi rusak }\end{array}$ & \multirow{2}{*}{$\begin{array}{l}\text { Customer Segments } \\
\text { Secara umum: } \\
\text { - Pecinta kuliner } \\
\text { - Pecinta K-pop } \\
\text { - Pecinta aksesoris } \\
\text { Golongan ekonomi: } \\
\text { - Masyarakat } \\
\text { menengah kebawah } \\
\text { atau menengah ke } \\
\text { atas } \\
\text { Pekerjaan: } \\
\text { - Pelajar/mahasiswa } \\
\text { - Pegawai } \\
\text { - Anak-anak } \\
\text { - Ibu rumah tangga } \\
\text { Wilayah: } \\
\text { - Tempat wisata } \\
\text { - Perumahan } \\
\text { - Perkantoran } \\
\end{array}$} \\
\hline & $\begin{array}{l}\text { Key Resources } \\
\text { - Sumber bahan baku } \\
\text { - Karyawan / Staff } \\
\text { - Produk unggulan } \\
\text { - Channels }\end{array}$ & & $\begin{array}{l}\text { Channels } \\
\text { - Media sosial } \\
\text { - Website } \\
\text { - Brosur } \\
\text { - Showroom/Bazar } \\
\text { Kartu nama } \\
\end{array}$ & \\
\hline $\begin{array}{l}\text { Cost Structure } \\
\text { - Biaya bahan baku } \\
\text { - Biaya tenaga kerja } \\
\text { - Biaya overhead } \\
\text { - Biaya administrasi }\end{array}$ & $\begin{array}{l}\text { Biaya penjualan } \\
\text { Biaya promosi } \\
\text { Biaya air, listrik, telepon } \\
\text { Biaya pajak }\end{array}$ & \multicolumn{2}{|c|}{$\begin{array}{l}\text { Revenue Streams } \\
\text { - Pendapatan penjualan produk } \\
\text { - Pembelian kartu member } \\
\text { - Pembelian voucher member }\end{array}$} & \\
\hline
\end{tabular}

Gambar 5: Referensi Business Model Canvas (BMC)

\section{Proyeksi Analisis Finansial}

Selain ke-7 (tujuh) blok elemen non-finansial yang terdapat dalam Business Model Canvas (BMC), 2 blok elemen finansial di dalamnya yaitu Cost Structure dan Revenue Streams juga menjadi elemen yang cukup krusial dalam menjalankan kegiatan usaha. Seperti yang telah kita ketahui bahwa 10 responden pelaku usaha masih merasa bahwa laba bersih atau keuntungan yang diperoleh tidak sesuai dengan biaya dan tenaga yang dikeluarkan. Dengan demikian memproyeksikan finansial diperlukan untuk mengetahui kelayakan dan keberlangsungan kegiatan usaha yang sedang dijalani. Perhitungan proyeksi analisis finansial kemudian akan dijabarkan oleh peneliti seperti dibawah ini:

\section{Perhitungan Cost Structure dan Revenue Streams}

Cost Structure merupakan seluruh biaya yang diperlukan dan dikeluarkan dalam melakukan suatu kegiatan usaha. Biaya-biaya yang perlu diperhitungkan tersebut di antaranya adalah harga pokok produksi (biaya bahan baku (biaya tetap/bahan tidak habis pakai dan biaya variabel/bahan habis pakai), biaya tenaga kerja dan biaya overhead), biaya administrasi, biaya penjualan, biaya promosi, biaya utilitas (biaya air, listrik, telepon), biaya renovasi, biaya pajak dan biaya lain-lain. Menghitung harga pokok produksi menjadi hal penting yang harus dilakukan agar pelaku usaha dapat mengetahui harga pokok penjualan dari suatu produk yang dihasilkan sehingga harga jual suatu produk ditentukan dengan tepat sesuai 
dengan biaya dan usaha yang dikelurakan. Berikut merupakan perhitungan harga pokok produksi, harga pokok penjualan dan harga jual (Noviasari \& Alamsyah, 2020).

$$
\begin{aligned}
\text { Harga Pokok Produksi }= & \text { Biaya Tetap }+ \text { Biaya Variabel }+ \text { Biaya Tenaga } \\
& \text { Kerja }+ \text { Biaya Overhead }
\end{aligned}
$$

Harga Pokok Penjualan/unit $=\frac{\text { Harga Pokok Produksi }}{\text { Jumlah Produk yang Dihasilkan }}$

$$
\text { Harga Jual/unit } \quad=\mathrm{HPP} / \text { unit }+ \text { Margin Laba }
$$

Revenue Streams merupakan pendapatan yang diperoleh dari penjualan barang atau jasa kepada para konsumen serta pendapatan lain di luar kegiatan utama. Maka dari itu, perhitungan Cost Structure yang tepat dapat membantu pendapatan menjadi lebih maksimal sehingga keberlangsungan kegiatan usaha lebih terjamin. Para pelaku usaha dapat mengetahui Revenue Streams berdasarkan dua perhitungan.

Hasil Usaha yang Akan Diperoleh = Harga Jual x Unit

Keuntungan yang Akan Diperoleh = Hail Usaha yang Akan Diperoleh - HPP

\section{Proyeksi Payback Period (PP)}

Dengan menghitung Payback Period para pelaku usaha dapat mengetahui jangka waktu pengembalian seluruh investasi atau modal yang telah dikeluarkan untuk melakukan kegiatan usaha yang dihitung dari aliran kas bersih (Steven Fredrik Josef Manopo J. Tjakra, R. J. M. Mandagi, 2013). Periode rata-rata dari payback period suatu kegiatan usaha adalah 3 tahun. Para pelaku usaha dapat menghitung proyeksi Payback Period dengan cara:

$$
\text { Payback Period }=\frac{\text { Investasi }}{\text { Kas Bersih/tahun }} \times 1 \text { tahun }
$$

\section{Proyeksi Break Event Point (BEP)}

Dari Revenue Streams dan Cost Structure yang telah disusun dalam Business Model Canvas (BMC), selanjutnya perhitungan dari analisa Break Event Point 
(BEP) digunakan sebagai tolak ukur kelayakan kegiatan usaha. BEP (titik impas) merupakan suatu titik di mana tidak mengalami keuntungan ataupun kerugian, maka dari itu analisis BEP dapat digunakan untuk perencanaan laba, perubahan biaya, perubahan harga, penentuan harga jual (Lumintang, 2014). Para pelaku usaha dapat menghitung proyeksi BEP dalam unit dan BEP dalam rupiah dengan cara:

$$
\begin{array}{ll}
\mathrm{BEP}_{\text {(dalam unit) }} & =\frac{\text { Biaya Tetap }}{\text { Harga Jual per unit }- \text { Biaya Variabel per unit }} \\
\text { atau BEP (dalam unit) } & =\frac{\text { Total Biaya }}{\text { Harga Penjualan }} \\
\mathrm{BEP}_{\text {(dalam Rupiah) }} & =\frac{\text { Biaya Tetap }}{1-\frac{\text { Biayga Variabel }}{\text { Penjualan }}} \\
\text { atau BEP (dalam Rupiah) } & =\frac{\text { Total Biaya }}{\text { Total Produksi }}
\end{array}
$$

Bila penjualan konsisten dalam mencapai angka yang dihasilkan dari perhitungan BEP, kegiatan usaha dianggap layak untuk tetap dipertahankan dan keberlangsungan kegiatan usaha juga lebih terjamin.

\section{SIMPULAN}

\section{Simpulan}

Berdasarkan hasil dan pembahasan di atas dapat disimpulkan bahwa sebagian besar pelaku UMKM yang ada di sekitar daerah Pamulang merasa bahwa laba atau keuntungan yang mereka terima masih belum maksimal dan belum sesuai dengan waktu dan usaha yang telah dikorbankan. Pengetahuan akan Business Model Canvas (BMC) dikalangan pelaku UMKM yang ada di sekitar daerah Pamulang masih sangat minim. Hal ini dibuktikan dengan tidak diterapkannya Business Model Canvas (BMC) oleh pelaku UMKM dalam menjalankan kegiatan usahanya.

Penerapan model bisnis dengan Business Model Canvas (BMC) dan proyeksi analisis finansial sangat diperlukan untuk dapat mempertahankan keberlangsungan kegiatan UMKM yang sedang dijalani. Hal tersebut dapat dimulai dengan melakukan analisis SWOT terlebih dahulu untuk mengetahui kekuatan dan kelemahan dari usaha yang dimiliki baru setelah itu 9 (sembilan) blok elemen dalam Business Model Canvas (BMC) dapat dijadikan sebagai fokus strategi bagi para pelaku 
usaha dalam mendirikan dan menjalankan kegiatan usahanya. Kesinambungan strategi dalam 9 (sembilan) blok elemen dianggap mampu menjadi solusi permasalahan yang masih sering dialami oleh para pelaku UMKMdi daerah Pamulang. Elemen non-finansial dalam Business Model Canvas (BMC) akan mendatangkan efektifitas waku dalam kegiatan produksi suatu usaha. Sedangkan elemen finansial dalam Business Model Canvas (BMC) akan mendatangkan efisiensi biaya dalam menjalankan kegiatan usaha karena pelaku UMKM telah melakukan proyeksi finansial dengan menghitung biaya produksi, harga pokok penjualan, harga penjualan, hasil usaha yang akan diperoleh, keuntungan yang akan diperoleh sehingga laba yang diperoleh dapat lebih maksimal dan sesuai dengan usaha yang telah dikeluarkan. Perhitungan break event point (BEP) dan payback period dapat memberikan gambaran bagi kegiatan usaha yang sedang dijalankan layak untuk dipertahankan serta lebih terjamin keberlangsungannya.

\section{Saran}

Untuk penelitian selanjutnya diharapkan mampu mengembangkan dan memberikan contoh penerapan Business Model Canvas (BMC) serta proyeksi analisis finansial yang lebih spesifik untuk membantu keberlangsungan suatu UMKM. Cakupan daerah penelitian serta responden juga diharapkan dapat diperluas serta dapat dilakukan di berbagai daerah di Indonesia sehingga keberlangungan kegiatan usaha dapat lebih terjamin. Pengimplementasian dan sosialisasi secara nyata mengenai model bisnis yakni Business Model Canvas (BMC), analisis matriks SWOT serta poyeksi analisis finansial diharapkan dapat benar-benar dilaksanakan agar wawasan dan pengetahuan mengenai hal tersebut dapat diketahui lebih luas dan dapat benarbenar diterapkan dan dilaksanakan, sehingga keberlangsungan ide kreatif yang ada dapat lebih terjamin dan dapat disalurkan berdasarkan perancangan strategi-strategi yang ada di dalam Business Model Canvas (BMC).

\section{DAFTAR PUSTAKA}

Assauri, S. (2016). Strategic Management. Sustainable Competitive Advantages ed.2. PT Grafindo Persada.

BPS. (2020). Tingkat Pengangguran Terbuka Menurut Provinsi (Persen), 20192020. https://www.bps.go.id/indicator/6/543/1/tingkat-pengangguran-terbukamenurut-provinsi.html 
Gischa, S. (2020). Jumlah Penduduk Indonesia 2020. https://www.kompas.com/skola/read/2020/01/08/060000069/jumlahpenduduk-indonesia-2020?page $=$ all

Hengki, Rizan, O. (2016). Prototipe E-Commerce Berdasarkan Konsep Business Model Canvas ( BMC) Untuk Meningkatkan Daya Saing. Proceeding of Conference on Information Technology, Information System and Electrical Engineering.

Hermawan, A., \& Pravitasari, J. (2013). Business Model Canvas ( Kanvas Model Bisnis ). Akselerasi.Id.

Khodijah, I. S., \& Ghina, A. (2016). Analisis Pengembangan Usaha Mikro Kecil Menengah (UMKM) pada Pengrajin Kursi Sofa Cipacing, Jatinangor Dengan Pendekatan Business Model Canvas.

Kurniawan, F. A. (2017). Pendekatan Business Model Canvas Sebagai Perancangan Strategi Bisnis Baru (Studi Pada UMKM UD. Gading Mas Pasuruan). Yudharta.

Lumintang, F. M. (2014). Analisis Pendapatan Petani Padi di Desa Teep Kecamatan Langowan Timur. Jurnal EMBA.

Nasip, I. (2017). Model Bisnis Kanvas: Alat Untuk Mengidentifikasi. 1 National Conference on Business and Entrepreneurship.

Noviasari, E., \& Alamsyah, R. (2020). Peranan Perhitungan Harga Pokok Produksi Pendekatan Full Costing Dalam Menentukan Harga Jual Dengan Metode Cost Plus Pricing. Jurnal Ilmiah Akuntansi Kesatuan. https://doi.org/10.37641/jiakes.v8i1.287

Osterwalder, A., \& Yves, P. (2010). Business Model Generation (J. Willey \& S. Hoboken (eds.)). books.google.co.id/books?hl=id\&lr=\&id=UzuTAwAAQBAJ\&oi=fnd\&pg=PA 9\&dq=related:gerOsXUEURwJ:scholar.google.com/\&ots=yYBPxaK40z\&sig= IVa7nsPwnun0Q5Ju73_qjdcpL64\&redir_esc $=\mathrm{y} \# \mathrm{v}=$ onepage\&q\&f=false

Osterwalder, A., \& Yves, P. (2012). Business Model Generation. PT Elex Media Komputindo.

Permana, D. . (2013). Analisis Peluang Bisnis Media Cetak Melalui Pendekatan Bisnis Model Canvas Untuk Menentukan Strategi Bisnis Baru. Jurusan Teknik Industri, Fakultas Teknik, Matematika Dan IPA, Universitas Indraprasta PGRI.

Phadermrod, B., Crowder, R. M., \& Wills, G. B. (2019). Importance-Performance Analysis based SWOT analysis. International Journal of Information Management. https://doi.org/10.1016/j.ijinfomgt.2016.03.009

Solihah, E., Hubeis, A. V. S., \& Maulana, A. (2016). Analisis Model Bisnis Pada Knm Fish Farm Dengan Pendekatan Business Model Canvas (Bmc). Jurnal Sosial Ekonomi Kelautan Dan Perikanan. 
https://doi.org/10.15578/jsekp.v9i2.1220

Solihin, I. (2012). Manajemen Strategik. Erlangga.

Steven Fredrik Josef Manopo J. Tjakra, R. J. M. Mandagi, M. S. (2013). Analisis Biaya Investasi pada Perumahan Griya Paniki Indah. Jurnal Sipil Statik.

Wisnu, S. D. (2014). Penggunaan Business Model Canvas Sebagai Dasar Untuk Menciptakan Alternatif Strategi Bisnis Dan Kelayakan Usaha. Jurnal Teknik Industri Universitas Trisakti. 